Statistics.-The Montyon Prize to Michel Huber, for the whole of his work in statistics.

History and Philosophy of Science.--The Binoux Prize between Paul Nève de Mévergnies (2,000 francs), for his memoir on Jean Baptiste van Helmont, and Charles Cabanes (1,500 franes), for his work on Denys Papin.

Works of Science.-The Henri de Parville Prize between Georges Bruhat (3,000 francs), for his book on thermodynamics, electricity, optics and physical mechanics, Guillaume Grandidier (2,000 francs), for his atlas of the French colonies, protectorates and territories under French mandate, and Pierre Gauja (2,000 francs), for his study on "L'Académie des Sciences de l'Institut de France".

Medals. - The Berthelot Medal to Paul de Graeve, Paul Job and Maurice Rangier.

General Prizes.-Prize founded by the State (mathematical sciences) to Maurice Gevrey, for his work on partial differential equations; the Bordin Prize to Henri Termier, for his important geological studies on central Morocco and the northern MoyenAtlas ; the Lallemand Prize to Ivan Bertrand, for his memoir on micrography in infra-red light and its application to renal cytology; the Vaillant Prize to Père Lejay, for his researches on the determination of gravity in the Far East; the Le Conte Prize to the late Julien Costantin, for the whole of his work; the Jean Reynaud Prize to Alfred Lacroix, for the whole of his scientific work; the Baron de Joest Prize to Paul Robert, for his researches on anallagmatic geometry and its relations with projective geometry; the Houllevigue Prize to Etienne Wolff, for his researches in experimental embryogeny and teratogenesis; the Parkin Prize $(2,400$ francs) to
Jean Jacques Bouckaert and Fernand Jourdan, for their work on the pharmacodynamics of the cerebral vessels ; an encouragement (1,000 francs) to Bernard Ménétrel, for his memoir on intravenous activated carbon in therapeutics; the Saintour prize to Robert Weill, for his work entitled "Contribution à l'étude des Cnidaires et de leur nématocystes" ; the Lonchampt Prize to Paul Meunier, for his researches on aluminium in animals; the Henri Wilde Prize to Georges Dupont, for the whole of his chemical work; the Caméré Prize to Lucien Chadenson, for his work in hydraulics; the Gustave Roux Prize to Henri Erhart, for his treatise on pedology; the Thorlet Prize to Paul Dorveaux; the Albert I of Monaco Prize to Fernand Holweck, for his work on the Holweck-Lejay pendulum; the Marquet Prize to Gustave Ribaud, for his researches on high tempera. tures ; the Alexandre Darrasq Prize to Etienne Audibert, Ferdinand Vallette and Francis Michot-Dupont (20,000 francs each), for methods of preparing petrol and benzene from materials obtained in France.

Prizes of the Grandes Ecoles.-The Laplace Prize to Robert Gachet; the L. E. Rivot Prize between Robert Gachet, Paul Cusset, Charles Mallet and Albert Jouvent.

General Foundations for Scientific Research.-The Gegner Foundation to the late Maurice Parat, for his work on the physiology of the cell; the Jérôme Ponti Foundation to Henri Besairie, for his work on the geology of Madagascar; the Hirn Foundation to Albert Arnulf, for his work in applied optics; the Henri Becquerel Foundation to Carl Benedicks, for his discoveries on the homogeneous thermoelectric effect.

(To be continued.)

\title{
Progressive Teaching in Geography
}

\section{The Geographical Association}

$\mathrm{T}$ HE Annual Conference of the Geographical Association was held at the London School of Fconomics on January 5-7.

At the first lecture meeting, Dr. L. Dudley Stamp dealt with Portugal in 1936 and entered a plea for geographers to accord separate consideration to Spain and Portugal rather than to group the two together, which they frequently do, as the Iberian Peninsula. The cultural background and history so clearly demarcate the two that the visitor cannot help being struck by the differences, which indeed recent events have emphasized. By means of lantern slides the remarkable changes witnessed in a traverse from north to south were demonstrated, and a tentative division of the country was suggested into the north-west, the north-east, the middle Douro basin (the port-wine area), the coastal belt, north centre, south centre (these two separated by the Tagus), the southern Sierra, and the Algarve.

On January 6, Sir William Beveridge took the chair at an important symposium on "Whither Population?" in which Prof. C. B. Fawcett stressed the spatial distribution of the world's population, and Dr. R. R. Kuczynski the changing distribution in time. Prof. Fawcett demonstrated that modern development and migration are not filling up the empty spaces of the world but, on the contrary, the great cities are increasing relatively to the whole and the pioneer fringe is moving back. Even in densely populated Great Britain, rural depopulation has been in progress for many decades, and one-fifth of the land surface has more than fifty-eight per cent of the people (compared with fifty-one per cent ten years ago). In Canada, forty-two per cent of the people live on less than one per cent of the land; in the United States, more than fifty per cent on less than two per cent; in Australia, more than fifty per cent in the capital cities alone. Dr. Kuczynski developed his now well-known theory of population increasethat the true measure is the relation between women of child-bearing age and births of female childrenbetween the mothers of to-day and the mothers of to-morrow. Where this net reproduction-rate falls below 1, the population must decrease. It is actually below 1 in all the countries of northern and western Furope, except the Irish Free State and Poland. It reaches its highest European figure now in the U.S.S.R. (more than 1.2). In Japan it is about $1 \cdot 4$. At present in Great Britain it is about $0 \cdot 75$, represent. ing a decrease of one per cent per annum. The population at this rate will fall bolow 30 million by 2000 A.D. and below 20 million in 2036. As Sir 
William Beveridge, in a masterly summary, pointed out, this may be desirable, but the process of change is bound to be painful. The arrest of the decline can be accomplished only slowly and in one way alone-by increasing the desire of the people to have children. Referenco was made to existing tax concessions as being a bad joke or, alternatively, a penny in the pound towards the cost of child-rearing. It was suggested that serious State action has nowhere been attempted. The two great questions are thus: Do we want to stop the decline? If so, can we?

A valuable discussion was that on broadcast geography lessons, at which the teachers, the inspectors, the B.B.C., and broadcasters were represented. There was general agreement that systematic lessons should not be attempted, but that first-hand travel talks to be used as 'background' material, and accurate as well as useful and stimulating in content, should be the aim.

Dr. H. A. Matthews detailed suggestions for the study of local climate and had some remarkable illustrations of local variations-the frost pockets by walls so well known to gardeners, the contrasts between the wind rose at the head of a valley (with one calm day per month and predominantly southwest winds) and at a village in the valley only one mile away (with fourteen calm days and the wind predominantly north-west or down the valley).

Mr. G. H. J. Daysh summarized his very important recent work on Tyneside and the north-east, emphasizing two points specially - the contrast between the reviving water-side areas and the stagnant inland coal mining areas, and secondly, his own faith in emigration as the solution.

Mr. S. H. Beaver dealt with the scope of railway geography, and two meetings were devoted to joint sessions with the Leplay Society-with Dr. Stamp on Poland and Dr. L. R. Wood on Norway.

Sir Josiah Stamp's presidential address on "Geography and Economic Theory" can only be described as epoch-making in that it defined clearly, for the first time, the points of impact of two modern disciplines and has provided a gospel for future workers.

\section{INSTITUTE OF BRITISH GEOGRAPHERS}

The Institute of British Geographers held its annual meeting at the London School of Economics on January 6-7, Prof. R. N. Rudmose Brown replacing Prof. C. B. Fawcett in the presidential chair.

Mr. W. V. Lewis developed the theme of glacial plucking and corrie formation from the bergschrund hypothesis of Willard Johnson, stressing the importance of glacial sapping at the foot of corrie cliffs and the potency of summer melting. Dr. S. W. Wooldridge considered the later stages in the physiographical evolution of the London Basin, thus continuing his well-known work published in the Proceedings of the Geologists' Association.

Mr. F. H. W. Green gave a succinct and wellillustrated account of the water-meadow systems of Hampshire; Mr. K. H. Huggins suggested a functional classification of English towns into five major groups : primary production, major industries, other industries, local services and regional services. Miss A. F. A. Mutton presented a detailed study of the Black Forest region and $\mathrm{Mr}$. R. A. Pelham a study of the wool industry in the fourteenth century.

L. D. S.

\section{Mathematical Association}

\section{Annual Meeting}

$\mathrm{T}$ HE annual moeting of the Mathematical Associa tion was held at the Institute of Education, London, W.C.1, on January 4-5. At the business meeting, Prof. L. N. G. Filon was elected president for the ensuing year, and the officers were re-elected as follows: Treasurer: Mr. K. S. Snell ; Secretaries : Mr. G. L. Parsons and Miss M. Punnett; Librarian: Prof. E. H. Neville; Editor of the Mathematical Gazette: Mr. T. A. A. Broadbent.

The report of the Council refers to the continued growth of the Association, which now numbers nearly 1,600. The library of the Association has been enriched by gifts from the Royal Technical College, Glasgow, and $\mathrm{Mr}$. C. O. Tuckey ; also by an exchange effected by Prof. Neville with the Centre National de Documentation Pédagogique, Paris, as a result of which a very complete collection of French text. books has been acquired. Referenco is also made in the report to reviews of French and German textbooks which have appeared in the Mathematical Gazette. The Teaching Committces announce that a supplementary report on the teaching of geometry will appear shortly and also that a sub-committee has been appointed to collect information about mathematical films. The Association has become affiliated to the Conference of Educational Associations.
The outgoing president, Prof. A. R. Forsyth, in his address entitled "Applied Mathematies in School Training : Some General Considerations", compared the standards demanded of an entrance scholar to Cambridge at the present time with those demanded sixty years ago. He noticed that, while there has been some modification of method rather than of matter in pure mathematics, applied mathematics is in a general way practically the same at the present day as it was when he himself was an undergraduate. This, he considers, is scarcely less than surprising, having regard to modern applications, and he went on to offer some general observations on the ways in which this defect might be rectified.

Prof. Georg Wolff, of Düsseldorf, read a paper entitled "The Development of the Teaching of Geo. metry in Germany". He referred to the revolt against the traditional teaching of Euclid which occurred in England partly owing to the work of the A.I.G.T. (afterwards the Mathematical Association) and partly owing to the attacks of Prof. Perry and others. He outlined the phases of a similar revolt which took place in Germany, culminating in the report of the German Sub-Commission of the International Commission on the Teaching of Mathematics. In the newest developments of the subject (which date from 